Social Sciences on Contemporary Turkey

16 | 2013

Demographic Engineering - Part III

\title{
Demographic Knowledge, 'Race Suicide' and the Making of Racial Jews in Interwar Europe
}

Sandrine Bertaux

\section{(2) OpenEdition \\ 1 Journals}

Electronic version

URL: http://journals.openedition.org/ejts/4848

DOI: $10.4000 /$ ejts.4848

ISSN: $1773-0546$

Publisher

EJTS

Electronic reference

Sandrine Bertaux, "Demographic Knowledge, 'Race Suicide' and the Making of Racial Jews in Interwar Europe », European Journal of Turkish Studies [Online], 16 | 2013, Online since 10 December 2013, connection on 16 February 2020. URL : http://journals.openedition.org/ejts/4848 ; DOI : $10.4000 /$ ejts.4848

This text was automatically generated on 16 February 2020

(c) Some rights reserved / Creative Commons license 


\title{
Demographic Knowledge, 'Race Suicide' and the Making of Racial Jews in Interwar Europe
}

\author{
Sandrine Bertaux
}

\section{Introduction}

1 In their review of the endorsement of the term 'demographic engineering' in Ottoman and Turkish studies, Nikos Sigalas and Alexandre Toumarkine (2008: \$12) underscored three reasons why the term particularly gained the favor of some scholars: it supports the idea of continuity between the late Ottoman empire and the Turkish nation-state, it meets with a liberal critique of state planning understood as paving the way for violence against minorities, and it helps in circumventing the taboo imposed by state ideology and apparatus over its own repressive history towards minorities. It is this latter aspect Erik-Jan Zürcher (2008: 1) invokes to explain why he first used the term back in 2005. Fearing to be exposed to state reprisals, Turkish academics invited Zürcher to introduce a collective volume published in Turkish in Turkey in which he used the term demographic engineering (Zürcher 2005). Yet, as Sigalas and Toumarkine remark, state repression alone does not explain why the term took root. Indeed, Zürcher (2008: 1) concedes that it proved to be more than a tactical move, as 'demographic engineering' became a positive source of inspiration he found in a work by two demographers, the late Myron Weiner and Michael Teitelbaum (2001), in their co-authored book titled Political Demography, Demographic Engineering.

2 My contribution to this third issue is on rather than in demographic engineering. I take issue with a narration of the history of humanity as a 'struggle for demographic power' (Bookman 1997) underpinning the category of demographic engineering. I regard demographic engineering as naturalizing the connection between population, territory and security eschewing both the modern codification of the concept of population and its power effect. My argument is that the connection between security and population 
underlying the category of demographic engineering is not the 'natural' behavior of 'populations' it presents, and even promotes, but an artefact of demographic knowledge. Therefore, my aim is to shed light on the power effect of modern demographic knowledge -population theories, demographic concepts and methodology- as a way of a critique of the category of demographic engineering. It is beyond the scope of this essay to provide an overview of the historical legacy of viewing populations in struggle for survival; rather, I will limit myself to a few instances. I organize my essay as follows: first I discuss some of the basic assumptions in demographic engineering literature and oppose to it Michel Foucault's concept of bio-politics of the population. In the second section, I address the connection between security and population in population theories and its reformulation in interwar Europe within the 'racial suicide' discourse. In the third section, I comment on genealogical graphs (published in Bertaux 2006: 296-297) from the archives of Demorazza, the General Direction for Demography and Race that was established to monitor the racial laws in fascist Italy in 1938, hosted at the Italian state archives in Rome. My aim is to show how the fiction of a first generation of separated populations (i.e. 'Aryans' and 'Jews') was a requirement for anti-Semitic politics. In the last section, I discuss the effect of using demographic concepts and methods to account for the Armenian genocide and count what becomes in such narrative, 'Armenian casualties.'

\section{Political Demography: the Population/Security Nexus}

3 Demographic engineering policies 'that caused the resettlement and ethnic cleansing of targeted populations,' Milica Zarkovic Bookman (1997: 4) argues, are not new for they 'have characterized Emperor Justinian's quests in North Africa; the Spanish expulsion of Jews and Moors from Spanish territory; European conquests of North and South American indigenous populations and the forcible removal of Africans for sale into slavery.' By bringing together different cases from different times and spaces, the demographic engineering literature renders the historical context irrelevant. To put on the same plane slave trade, forced migrations, state-led politics of (forced) assimilation, organized race riots, cases of genocide, mass exterminations and so forth is amenable to the critique brought a decade ago by Mark Mazower (2002: 1160) when he took issue with the ranking of 'the Holocaust as a historical benchmark for modern mass violence.' His point was that in the wake of the return of totalitarian theories, statecentered approaches to violence overlook non-state actors while categories of genocide and ethnic cleansing downplay specific contexts and say little or nothing about the weakness or strength of the state, and more broadly, power structure and dynamics. Whereas the revival of totalitarian theories aimed at opposing an ethnic explanation to ethnic hatred (Mazower 2002: 1159) I suggest that, demographic engineering tends to naturalize them. What is more, to contend that Europe between 1850 and 1950 experienced the 'age of demographic engineering' as Zürcher (2008: 1) does, relegates in fact the Holocaust as yet another instance in the long catalogue of human violence listed under the rubric of demographic engineering. If demographic engineering flattens rather than sheds light on these instances, and prevents us from recasting them both in their historic singularity and in comparative perspective, it is not because 
of a state-centered approach to violence and specific forms of state power (i.e. totalitarianism) but because what is at issue are struggles between populations.

Admittedly, demographic engineering found a favourable terrain for its promotion in the wake of heightened murderous ethnic-based conflicts and in the establishment of genocide, minority and conflict resolution studies in the 1990s in the United States (Sigalas and Toumarkine 2008: §34). Unlike the categories of genocide and ethnic cleansing that have been elaborated for legal purposes and at times, transferred into historical analysis, the category of demographic engineering however is borrowed from another field of study, the field of demographic studies. The question is no longer the way states manage their minorities or citizens at large, but the relationship between one population to another. The state is, in this perspective, the instrument of one population against other populations.

5 In the perspective of the sociology of knowledge, demographic engineering is a category that emerged from the will of demographers to create a new field of political demography. Arguing that the political implications of population trends and movements are central in the study of politics, they call for a new approach to the study of politics by bringing to the fore demographic expertise. One should bear in mind that demography or population studies are foremost taught under other wellestablished academic disciplines (such as historical demography) or other fields of study (for instance, urban, migration or health studies) on the one hand, and demographic research conducted under the auspices of state institutes such as the French National Institute for Demographic Studies (INED) or private foundations such as the US-based Population Council. Political demography is a new term for an old idea, namely that demography is a discipline of government.

Political demography was actively promoted in France in the early eighties. In 1982, an Interdisciplinary Seminar of Political Demography (SIDP) was held at the Collège de France, the highest French academic institution, and promoted by Alfred Sauvy, the long-term director of the INED and Honorary Professor at the Collège de France (Sauvy et al. 1982). It was organized by non-academic institutions, the Political Demography Institute and the Association for Demographic Research and Information (APRD), both presided by Gérard-François Dumont, who defined political demography as putting 'problems of population' into the life of the polis (Dumont 1982: 17). What were these population problems? Demographers argued that France was weakened by low fertility leading to an ageing trend and undermining its capacity to assimilate immigrants. Because those immigrants deemed unassimilable in French demographic literature, the postcolonial labour migrants and their families, had settled in their former metropolis, demographers argued that French national identity was being radically altered (Bertaux 2000). These trends were not to be halted easily; countries of the Third World- a term coined by Sauvy in 1952- were experiencing high fertility rates whereas West European countries were encountering low fertility rates, and this would inevitably lead to more emigration from the Third World to Europe, putting Europe in danger of becoming 'submerged' by Third World immigrants (Sauvy 1987). French demographers could draw from a century-old demographic discourse that made a structural connection between labour immigration starting in the late nineteenth century in France, declining fertility and the future of national identity (Bertaux 2011). To reverse such trend they called for more 'native' births in order to maintain Frenchness. 'Native' is not a category based on citizenship distinguishing foreigners 
from citizens, or on birthplace distinguishing those born in France or abroad, but a racialized one that distinguished 'French of French stock' and those of 'immigrant background,' two mutually opposite categories codified in the 1990s (Bertaux 1997; Bertaux 2000).

7 It is no coincidence that differential fertility rates and international migrations are the core themes of political demography (Teitelbaum and Winter 1998; Demeny and McNicoll 2006). A case in point in political demographic expertise is provided by Population Council demographer Paul Demeny (1986). To counter low fertility rates in Europe and in order to avoid both immigration or welfare provisions as remedies, Demeny suggested nothing less than exchanging universal suffrage for a family-based electoral system, in which parents cast votes on behalf of their children. This vote familial was a central proposition to interwar French pro-natalist demographers against the granting of political rights to French women, which they eventually gained in 1944 . The family vote sought to give them subordinated political rights within a patriarchal system that recognized women as mothers, wives or widows rather than as individual citizens (Bertaux 2011). My point is that demographic engineering is hardly an analytical category ; it is too or even foremost a policy-making category.

Demographic language is foremost a language of identity staging the 'we' against the 'them'; this is a language of security. Whether it is about 'depopulation' or 'overpopulation,' as Ian Hacking (2002: 18) remarks the 'population problem' is always posited in relative terms for it 'denotes both the population explosion of other peoples and too low birth rate of one's own people.' Political demography is predicated on the assumption that there is an inherent connection between population and security (for instance, Goldstone et al. 2012). Herein, Weiner and Teitelbaum (2001: ix) write: 'Population- its growth or decline, its movement, its density, its characteristics, its distribution- has always been linked to questions of security. The movement of peoples has made and unmade states, and transformed societies.' It begs the question, what constitutes a population in political demography? Populations are more than a mere aggregate of individuals or a concept of population that is linked to territorial sovereignty and designates the inhabitants under a sovereign power in a delimited territory; instead, individuals are bound up by a common identity. The concept of population in political demography is best understood, I believe, as a biological closed reproductive group endowed with a common identity. That ethnic groups and populations are interchangeable is clear in Milica Zarkovic Bookman (1997: 1) when she defines demographic engineering as a 'war of numbers' in order 'to increase the economic and political power of an ethnic group relative to others, and the method by which this is achieved entails the increase in the size of one population relative to others.' Herein, populations are primordial categories that pre-exist the state and 'societies.' The least that can be said is that such an approach naturalizes power relations by reifying the state, obfuscates internal heterogeneity based on class, gender, and inherent cultural diversity of various groupings, contributing to give an essentialist definition to ethnic groups.

Contrary to such naturalizing effects on which the field of political demography is premised on, I contend that population is a modern concept and an artefact of demographic knowledge that turns populations and their intrinsic biological features into a security issue. Recapturing the history of the modern concept of population and its intricacy in modern forms of power in Western societies was central to Michel 
Foucault's concept of biopolitics. Foucault $(1978,137-138)$ pointed out how the rise of demographic knowledge in the eighteenth century - and with it population statisticssignalled a transformation of power in which the 'ancient right to take life and let live was replaced by the power to foster life or disallow it to the point of death.' In biopower, the stake is no longer sovereignty juridically defined but 'the biological existence of a population.' He wrote, 'If genocide is indeed the dream of modern powers, this is not because of a recent return of the ancient right to kill ; it is because power is situated and exercised at the level of life, the species, the race, and the largescale phenomena of population.'

Demographic engineering does more than ignoring contexts; it erases the role of demographic knowledge. By positing population as an independent variable, stripped out of its historical and political economic context, it leads to believe that it is an easily manipulable object. Turning a population into a security matter is not a theoretical view but becomes a matter of necessity. Political demography (and demographic engineering) are antithetical to Foucault's concept of the biopolitics of the population, in another dimension. With the concept of biopolitics, Foucault aimed at laying down a theory of racism in which difference or 'other populations' do not pre-exist racist politics but are constituted by it. In demographic engineering populations are the very cause of racism, thereby racist politics becomes a natural attribute of humanity in its inherent diversity. Ultimately, to regard the Holocaust as an ethnic conflict in Europe, as if the Aryans were an ethnic group that succeeded in seizing power, is no small victory to Aryan ideology.

\section{Population Theory, the 'Struggle for Population' and 'Race Suicide'}

11 The connection between population and security was central to Thomas Robert Malthus who elaborated the first comprehensive population theory. With his Essay on the Principle of Population, first published anonymously in 1798, and duly authored in its subsequent revised and enlarged editions, Malthus provided the European bourgeoisie its justification not to confront the social question he gave a 'natural' cause, fertility. Against the ideas and ideals of the supporters of the French revolution, Malthus aimed to demonstrate that human institutions and hierarchies were shaped by the 'principle of population' - or human fertility - and therefore, not amenable to social reform. Even worse, he argued that any attempt to relieve poverty, by missing its cause, would lead to the opposite outcome. Malthus was the first to hold a chair in Modern History and Political Economy in England in 1805 (Collini et al. 1983: 67) and he is today widely regarded as the father of demography.

Malthus (1976/1798) explained that 'population, when unchecked, increases in a geometrical ratio' whereas 'subsistence increases only in an arithmetical ratio.' This unbalance creates the conditions for a struggle over subsistence that results in the negative checks that are war, misery, and vice. To avoid overpopulation, he suggested some remedies shaped by his religious system of morality. Condemning the disconnection between sexuality and procreation on the one hand and sexuality outside marriage on the other, he suggested that the poor engage in a 'moral restraint,' namely pre-marital sexual abstinence, or even to the abandonment of marriage 
altogether, that is, to life-long sexual abstinence. Infamously, Malthus $(1992 / 1803,249)$ denied a right to the means of subsistence:

'A man who is born into a world already possessed, if he cannot get subsistence from his parents on whom he has just demand, and if the society do[es] not want his labour, has no claim of right to the smallest portion of food, and in fact, has no business to be where he is. At nature's mighty feast there is no vacant cover for him. She tells him to be gone, and will quickly execute her own orders, if he does not work upon the compassion of some of her guests.'

For Karl Marx (Grundisse 1857/58, in Tucker 1976: 277), not only did Malthus gave a 'brutal expression to the brutal viewpoint of capital' but elaborated the fallacy of a natural overpopulation when treating 'overpopulation as being of the same kind in all the different historic phases of economic development.' Malthus 'does not understand their specific difference, and hence stupidly reduces these very complicated and varying relations to a single relation, two equations, in which the natural reproduction of humanity appears on the one side, and the natural reproduction of edible plants (or means of subsistence) on the other, as two natural series, the former geometric and the latter arithmetic in progression.' For Marx, surplus population was relative, and not related to the means of subsistence but to the condition of producing them and the 'Malthusian natural man' is to be found only in Malthus' population theory and political economy, not in history.

Nevertheless, the naturalization of reproduction as an ahistorical law or a principle of population remained influential and indeed inspired Charles Darwin (2003/1859: 135) in his elaboration of the theory of evolution. Darwin acknowledges his debt to 'the doctrine of Malthus':

'Hence, as more individuals are produced than can possibly survive, there must in every case be a struggle for existence, either one individual with another of the same species, or with the individual of distinct species, or with the physical condition of life (...) for in this case there can be no artificial increase of food, and no prudential restraint from marriage. Although some species may be now increasing, more or less rapidly in numbers, all cannot do so, for the world would not hold them.'

In 1880s, inspired by Darwin's concepts of natural and sexual selection, Francis Galton coined the term 'eugenics' to designate a new science of human heredity. Galton's eugenics was based on the belief that social hierarchy has a biological base, but as higher social classes had fewer children than lower classes, many eugenicists believed that the nation would soon be in the hands of the lower classes they despised. The encounter between Malthus' fear of the prolific lower classes with the science of the well-born, in the new era of the masses, brought a new question to the fore: would the future of the nation belongs to those who reproduce more - the masses - rather than the elite? Power is no longer in the monopolization of means of production, wealth and intellectual leadership; it is fundamentally one related with numbers, innate qualities and fitness. In addition, as birth rates displayed steady declining trends in many West European countries, there was a concern with depopulation.

The theme of 'racial suicide' captured aspects of both quality and quantity, one of degeneration as the unfit took over the nation, and one of decadence as the number of nationals would decrease. This view was exemplified by American biologist Raymond Pearl (1912: 48) who stated at the First International Congress of Eugenics in 1912:

'The progressive decline of the birth rate in all, or nearly all, civilized countries is an obvious and impressive fact. Equally obvious and much more disturbing is the 
fact that this decline is differential... generally it is true that those racial stocks which by common agreement are of high, if not the highest, value, to the state or nation, are precisely the ones where the decline in reproduction rate has been most marked.'

17 Pearl devised his own theory of population - the logistic S curve (Ramsden 2002) providing a law of diminishing fertility. Drawing from his experiments with fruit flies (drosophila) in petri dishes, Pearl (1939) argued that A Natural History of Population could be written based on a law of density and growth applying to all living organisms. Against Malthus' population theory, Pearl claimed that populations reach, after a certain point, their saturation point. To make clear how 'natural' Pearl believed population trends in fertility and mortality to be is exemplified by the fact that he took as a case in point the native population in French Algeria. Denying the impact of colonization was to deny fertility as a product of complex social arrangements. Pearl was not the only scholar to elaborate a population theory alternative to Malthus. Corrado Gini, the influential demographer of the Italian fascist regime, sought too to explain how 'nations' are born, mature and eventually die out. Gini suggested that Italians could regenerate the 'old' nations in decay, namely Britain and France (Bertaux 1999).

18 My aim is not to narrate the complex history of transnational debates over the impact of the uneven distribution of fertility rates across social classes, races, cultural groups or nations, or the politics of population implemented in their wake. Rather, I want to underscore how populations were apprehended in their biological features and made available to political intervention. Ever since Malthus, fertility was regarded as a natural and independent variable. Demography was thought and practiced as a biosocial field of study, and in fact, population theoreticians rejected the title of demographer. One major obstacle remained: how could fertility be properly measured? Once again the question was solved through furthering the naturalization and desocialization of fertility. Among others, Alfred James Lotka (1939) gave fertility its mathematical codification. He elaborated the model of stable population - exposed in his book Théorie analytique des associations biologiques (Analytical Theory of Biological Associations)- according to which closed populations, i.e. without migration movements and, with constant fertility and mortality rates would have a constant rate of growth. Ever since, it remains central to population studies (see my last section). This new calculus is based on women alone or what is known as the 'one-sex model.' With the new codifications of fertility, the question was not as previously how many births for how many people, but how many surviving women in the age of procreation will give birth to how many daughters. The social aspect of reproduction, and its political economic context, is definitively erased. Consequentially, mortality does not have the same meaning for all the components of the population: that of a baby girl does not have the same value as that of an old man; nor is that of a woman after her procreative period.

19 In the 1930s, the codification of fertility made population forecasting easier. Population projections depicted West European nations on the verge of extinction, and ultimately, the white population as a whole, likely to be submerged by non-white races, a cause or/ and a symptom of European decadence. Populations were ageing and lacked the vitality of 'youth.' The discourse of a specific 'white race suicide' was staged through statistical tables, novel graphic representations including population pyramids, and population forecasts. For instance, French population and economic statistician Alfred Sauvy 
(1936) I mentioned earlier, wrote in the Encyclopédie française a demographic piece inspired by the vitalism promoted in fascist regimes: 'If German and German-Latin peoples, actually living upon an acquired speed' are doomed 'to ageing and decline,' if 'peoples from central Europe' are engaged in the same trend of 'decadence' with some delay, 'yellow populations do not give any sign of decay. In between the two worlds, Russia remains the great enigma of tomorrow and, even of today. Its evolution will decisively influence the demographic and political future of Europe.' In Sauvy's text, the threat is coming from Bolshevik Russia rather than fascist regimes which, unlike the Soviet Union, were actively trying to raise their fertility rate to claim greater space for their prolific nations. French demographers lauded fascist politics of population they misrepresented as 'pro-natalist' (Bertaux 2005, 2011).

This misrepresentation - politically convenient - obfuscated the fact that slogans such as 'strength in numbers' (Mussolini) or that the view of women as mothers in Nazi Germany concealed that what constituted the highest biological value for the nation and its imperial designs, or the white race, was a continuous object of elaboration. The Struggle for Population (Glass 1936), as one British scholar called it, was predicated on the 'natural extinction' of West European nations. Obviously, this did not occur. Nazi Germany led simultaneously pro- and anti-natalist policy according to different 'populations' to the point of suppressing the 'lives unworthy of life' and non-Aryans altogether (Bock 1983).

\section{The Making of Racial Jews: Genealogy and the Fiction of Purity in Fascist Italy}

On July $14^{\text {th }}, 1938$, a manifesto on Fascism and the Problems of Race - best known as the Manifesto of the Racist Scientists - published in Il Giornale d'Italia launched the antiSemitic campaign. While borrowing from Nazi Germany, the Italian racist politics already diversely enacted in Italian colonies to prevent racial mixing, was presented as a new turn in fascism. Signed by scientists, including the head of the Italian census bureau, it provided its scientific legitimacy to state racism. The manifesto aimed at explaining in 10 points to the Italian public that races are a scientific fact, and racism a suitable politics: 'It Is Time for Italians to Proclaim Themselves Frankly Racist' point 7 stated. The manifesto was wholly dedicated to prove that Jews were never assimilated in the Italian race and retained their racial features, while on the other hand, the Italian race was reconceptualized as part of the Aryan race. Published on Bastille Day, the manifesto argued that the emancipation of the Jews by the French Revolution - that is, the equality of status with Christian populations - did not lead, in Italy, to assimilation. Such a claim played out two different understandings of assimilation: a juridical one which, after the French revolution, emancipated the Jews, turning them into citizens, and a new eugenics understanding, that of miscegenation. To claim that Jews were never assimilated referred to the latter understanding in order to justify new legal discrimination against Jews: Jews never blended with the Italo-Aryan race.

With the racial laws in Italy, a new General Direction of Demography and Race -known as Demorazza - was created. How novel this conflation between population and race was is provided by four genealogical graphs in a single document from the archives of Demorazza. ${ }^{1}$ The document has the clear task for its anonymous author to make sense of what constitutes a racial Jew as proclaimed in the new law. It reveals how the civil 
servant juggles to comprehend the novel 'racial Jew,' hence that there was nothing evident in the passage from a religious definition to one based on race.

These graphs are important because they illustrate how the constitution of racial Jews and Italian-Aryans as two mutually exclusive categories does not draw from language, territory or nationality, the traditional categories of nationalism, but from genealogy. Many Italians born in Jewish families did not practice any religion, and an estimated one-third married outside the religious community, and a significant number had also converted to Catholicism. In the eye of the anti-Semitic laws, some were nevertheless ascribed to the state category of Jew. If names and registration in Jewish institutions served as means to track down a Jewish population, ultimately it was genealogy that helped to incorporate those who could not be held as Jews according to religious criteria or names, and ascribe to them a racial Jewish identity independent from religion. The making of racial Jews was foremost a demographic task, and it rests on the necessary fiction of purity at the first generation, namely when the individual is defined by one population or race.

All four genealogical trees represent three generations. The first genealogical tree (a) is dedicated to purity: all individuals represented by blue dots are represented as Jews, but even purity remains elusive to the anonymous civil servant who passes from the definition of Jews through 'family names' to end up defining it as 'pure blood' over three generations. It also obliges him to work with the reproductive concept of the couple when he had erased his first mention of family. The second genealogical tree (b) introduces a first intermarriage at the first generation when an Italian represented by a red dot marries with a Jew. At the third generation, the grand children are still 'Jewish blood' at $75 \%$. It is blatant that what is at issue is the third or 'present' generation. In the next graph (c), whether the intermarriage takes place at the second generation (c1) or at the first (c2), the last generation is half Jewish, half Italian. Whether they are considered of Aryan Italian race or of Jewish race is a matter of law. The last genealogical tree, racial Jew is introduced as the first generation giving birth to grandchildren with $25 \%$ of 'Jewish blood': therefore 'Italians' is the verdict. These genealogical trees are one instance of how demographic knowledge rests upon a fiction of purity that holds separate closed populations with reproductive power and examines its potential mixing. In the last section, I raise another question: how does this representation of populations as separated closed groups impact on the writing of history?

\section{V. 'Stable Populations' and the Case of Armenian 'Casualties'}

Numbers are at the core of negationist language. There is nothing curious that negationists draw from the authority of numbers and statistics because what is expected is a truth effect through the simple use of statistics and numbers. AntiSemitic laws, deportations, camps and so on, are made irrelevant to this numeric truth. There are more or less sophisticated versions of what I term the arithmetic negationism. If for long, providing lower numbers against those established by serious historical scholarship was sufficient for negationists to gain an audience, there are more sophisticated versions of arithmetic negationism today. The Armenian genocide is a case in point. 
26 As Marc Nichanian (2006) reminds us, the nature of genocide is 'to cancel itself as a fact.' Bringing the proof of the genocide is therefore playing into the hands of the executioners. Nichanian's reflexion on 'the historiographic perversion' that results from the essence of genocide of not being a fact in the case of the Catastrophe, is of utmost relevance in a discussion on demographic engineering. Recent discourses of 'forgiveness' and 'reconciliation' have perceptibly moved the Catastrophe from denial to recognition in Turkey. Yet, this move is preceded, and is perhaps sustained today as well, with a new arithmetic provided not from historical analysis but from the use of demographic concepts and methodologies.

In the early eighties, Justin McCarthy (1983) applied to Ottoman populations the model of stable populations forged by Alfred James Lotka, whom I mentioned above. Recall that the model is based on a closed population, excluding any migration movements. In the 1960s, it was used as an instrument at the Population Division of the United Nations to establish 'life tables' for countries lacking statistical data. It is one of the major instruments in demographic analysis today. Drawing from Lotka's stable population model, McCarthy reached the number of 600,000 Armenians casualties between 1914 and 1922. One may view McCarthy's work as one of the early work in political demography in the eighties, and indeed a successful transfer from demographic studies to historical investigation. His estimate is widely endorsed by historians and political scientists today. Yet few scholars seem aware that McCarthy draws from a demographic model and calculus and few question how McCarthy obtained the number of 600,000 or his underlying assumption in approaching the genocidal case of Ottoman Armenians through demographic concepts and methods. Once elaborated, these numbers acquire the power of truth and become a hard fact of history, demography and politics. It is surprising that his estimate has gained such authoritative value, and it does reveal that demographic and statistical methods still pass for having a superior scientific status as approximating the methods of natural or 'hard' sciences at the detriment of painstaking historical work.

Frédéric Paulin (2000) provides a thorough critique of McCarthy's use of the stable population model to investigate the death toll of Armenians. Paulin makes two related arguments. First, he reminds us that both the Ottoman state and the Armenian patriarchate provided different numbers on the Armenian population before the war, the former estimating at 1,3 million, the latter at 2,1 million. McCarthy compiles various sources with no serious grounding, Paulin argues. Second, Paulin forcefully shows how the requirements for the application of the model of stable populations are not met in the case of late Ottoman Empire. As I underscored earlier, Lotka's work emerged from the view of a natural history of populations grasped as biological reproductive groups. This method must be used only where variations in fertility and mortality are assumed to be small and where migrations have little impact on the studied population; this is not the case. Therefore, McCarthy's work fails by two scientific standards. It fails from the historical perspective of a critical appraisal of sources; it fails from the demographic standard in his application of stable population theory.

29 Reaching the 'true' or 'reasonable' number conceals how it puts in motion another historical narrative. Paulin unveils how this new arithmetic aims at recasting the two communities on the same footing as 'both murderers and both victims.' Away from the denial vs. recognition frame that prevails today, McCarthy revamps the Armenian 
genocide as an ethnic conflict. As Paulin points out, he obtains this confrontation between two 'different populations' only through an ungrounded move from proportion - the death rate among the Armenians is much greater than Muslims - to absolute numbers in which Muslims have a higher loss than Armenians. After Daniel Panzac, Paulin notes that most Armenians died from spring to winter in 1915 whereas most Muslims between 1916 and 1919. The confrontation thesis is simply ungrounded.

McCarthy's work is typical of how political demography in providing us with a specific narrative that naturalizes power and history. It also raises political questions: If the 'true' number is a preliminary step to the recognition of the Catastrophe, it also voids recognition from any meaning. The point I made earlier regarding the Holocaust is valid here as well: the Armenian genocide becomes another instance in the long murderous list under the rubric of demographic engineering. Its singularity and own voice are made irrelevant; it has no name. One should be concerned if calls to reconciliation are made on such flawed ground.

\section{Conclusion}

31 Demographic engineering may prove to have the opposite of the liberatory effect expected in late Ottoman and Turkish historiography, while providing a reductionist view of European history and historical analysis tout court. Demographic engineering or political demography, I suggest, are the offspring of population theories, demographic concepts and methods elaborated in the thirties when populations were no longer regarded as an aggregate of individuals but rather the individual bearers of different biological values, to be encouraged, discouraged, or prevented through reproduction or extermination. The de-historicizing effect of demographic engineering is all the more dangerous in that, by erasing the role of demographic thinking and knowledge in the problematization of the concept of population, it implies that demographic engineering is a requirement for having peaceful societies.

\section{BIBLIOGRAPHY}

Bertaux, Sandrine (2011) 'Reproduce or Perish? The Artefact of the Fertility Concept and the French School of Demography' Special issue 'Fertility in the History of the $20^{\text {th }}$ Century: Trends, Theories, Policies, Discourses' eds. Josef Ehmer, Jens Ehrhardt, Martin Kohli, Historical Social Research 36(2): 120-139. URL: http://www.jstor.org/stable/41151277 (accessed 10 December 2013). Bertaux, Sandrine (2006) Projecting the Nation. European States in the 1920s and 1930s. Ulusu tasarlamak. 1920'ler ve 1930'larda avrupa devletleri, Istanbul, Osmanlı Bankası Arşiv ve Araştısrma Merkezi.

Bertaux, Sandrine (2005) 'Démographes français et italiens : la construction du concept de "race juive" des années vingt aux années quarante,' in Matard-Bonucci, Marie-Anne (ed.) AntiséMythes. L'image des Juifs entre culture et politique (1848-1939), Paris, Nouveau Monde Éditions, pp. 107-127. 
Bertaux, Sandrine (2000) “"Processus" et "population" dans l'analyse démographique de l'immigration en France (1932-1996),' in Le Bras, Hervé (ed.) (with Sandrine Bertaux), L'invention des populations : biologie, idéologie, politique, Paris, Odile Jacob, pp. 241-254.

Bertaux, Sandrine (1999) 'Démographie, statistique et fascisme : Corrado Gini et l'Istat, entre science et idéologie (1926-1932)' Roma moderna e contemporanea 3, special issue 'Roma e la scienza': 571-598.

Bertaux, Sandrine (1997) 'Le concept démographique d'assimilation : un label scientifique pour le discours sur l'intégration ?,' Revue française des affaires sociales 2, special issue 'Insertion, intégration : concepts et pratiques': 37-51.

Bock, Gisela. (1983) 'Racism and Sexism in Nazi Germany: Motherhood, Compulsory Sterilization, and the State,' Signs 8 (3), special issue 'Women and Violence' :400-421. URL: http:// www.jstor.org/stable/3173945 (accessed 10 December 2013)

Bookman, Milica Zarkovic (1997) The Demographic Struggle for Power: The political economy of demographic engineering in the modern world, London, Frank Cass.

Collini, Stefan; Winch, Donald; Burrow, John (1983) That Noble Science of Politics: A study in nineteenth-century intellectual history, Cambridge, Cambridge University Press.

Darwin, Charles (2003) [1859] On the Origin of Species by Means of Natural Selection, Toronto, Broadview Press.

Demeny, Paul (1986) 'Pronatalist Policies in Low-Fertility Countries : Patterns, Performance and Prospects,' Population and Development Review, 12 (supplement): 335-358. URL: http:// www.jstor.org/stable/2807916 (accessed 10 December 2013)

Demeny, Paul; McNicoll, Geoffrey (2006) The Political Demography of the World System, 2000-2050, New York, Population Council. URL: http://www.popcouncil.org/pdfs/wp/213.pdf (accessed 10 December 2013).

Dumont, Gérard-François (1982) 'Introduction à la Démographie Politique’ in Sauvy, Alfred; Dumont, Gérard-François; Mérigot, Bernard (eds) Démographie politique, Paris, Economica, pp. 15-24.

Foucault, Michel (1978) The History of Sexuality: An introduction (trans. Rovert Hurley), New York, Vintage Books.

Glass, David Victor (1936) The Struggle for Population, Oxford, Clarendon Press.

Goldstone, Jack; Kaufmann, Eric P.; Duffy Toft, Monica (eds.) (2012) Political Demography: How population changes are reshaping international security and national politics, Oxford, Oxford University Press.

Hacking, Ian (2002) The Taming of Chance, Cambridge, Cambridge University Press.

Lotka, Alfred James (1939) Théorie analytique des associations biologiques, Paris, Hermann, vol. 2.

Malthus, Thomas Robert ([1798] 1976) An Essay on the Principle of Population (A. Flew, ed.), Harmondsworth, Penguin.

Malthus Thomas Robert ([1798] 1992) An Essay on the Principle of Population, D. Winch ed., Cambridge, Cambridge University Press.

McCarthy, Justin (1983) Muslims and Minorities: The population of Anatolia and the end of the Empire, New York, New York University Press. 
Mazower, Mark (2002) 'Violence and the State in the Twentieth Century,' American Historical Review 107 (4): 1158-1178. URL: http://www.jstor.org/stable/10.1086/532667 (accessed 10 December 2013).

Nichanian, Marc (2006) La perversion historiographique. Une réflexion arménienne, Paris, Lignes.

Paulin, Frédéric (2000). 'Négationnisme et théorie des populations stables : le cas du génocide armenien,' in Le Bras, Hervé (ed.) (with Sandrine Bertaux), L'invention des populations : biologie, idéologie, politique, Paris, Odile Jacob, pp. 161-176.

Pearl, Raymond (1912). 'The Inheritance of Fecundity,' in First Congress of Eugenics: Problems in eugenics, London, The Eugenics Education Society.

Pearl, Raymond (1939) The Natural History of Population, New York, Oxford Univesity Press.

Ramsden, Edmund (2002) 'Carving Up Population Science: Eugenics, Demography and the Controversy over the 'Biological Law' of Population Growth,' Social Studies of Science 32 : 857-899. URI : http://dx.doi.org/10.1177/030631270203200509 (accessed 10 December 2013).

Sauvy, Alfred (1936). 'Vitalité ou le pouvoir d'accroissement d'un peuple,' in Febvre, Lucien (ed.), L'Encyclopédie française, vol. VII: L'Espèce humaine (P. Rivet, ed.), chapter V, section C:

'Renouvellement des générations,' pp. 10-16.

Sauvy, Alfred (1987) L’Europe submergée. Sud-Nord dans 30 ans, Paris, Dunod.

Sigalas, Nikos; Toumarkine, Alexandre (2008) 'Ingénierie démographique, génocide, nettoyage ethnique. Les paradigmes dominants pour l'étude de la violence sur les populations minoritaires en Turquie et dans les Balkans,' European Journal of Turkish Studies 7, 'Demographic Engineering Part I'. URL: http://ejts.revues.org/2933 (accessed 10 December 2013).

Teitelbaum, Michael; Winter, Jay (1998) A Question of Numbers: High migration, low fertility, and the politics of national identity, New York, Hill and Wang.

Tucker, Robert C. (1978) The Marx-Engels Reader, 2d ed., New York, Norton.

Weiner, Myron; Teitelbaum, Michael S. (2001). Political Demography, Demographic Engineering, New York, Berghahn Books.

Zürcher, Erik-Jan (2005) (ed.) İmparatorluktan Cumhuriyete Türkiye'de Etnik Çatışması, Istanbul, İletişim.

Zürcher, Erik-Jan (2008) 'The Late Ottoman Empire as Laboratory of Demographic Engineering », in Le Regioni multilingui come faglia e motore della storia europea nel XIX-XX secolo, Napoli, 16-18 settembre 2008. URL: http://www.sissco.it/fileadmin/user_upload/Attivita/Convegni/ regioni_multilingue/zurcher.pdf (accessed 10 December 2013).

\section{NOTES}

1. Archivio Centrale dello Stato, Ministero dell'interno, Direzione per la Demografia e Razza (1938-1944), Parte prima fasc. 12. I. (See Bertaux 2006: 296-297.) 


\section{ABSTRACTS}

This essay takes a critical stance on the category of demographic engineering. I regard demographic engineering as naturalizing the connection between population, territory and security eschewing both the modern edge of the concept of population and its power effect. My argument is that the connection between security and population that is underlying demographic engineering is not a 'natural' behavior of 'populations' but an artefact of demographic knowledge that can be traced back to interwar Europe when the population/ security nexus was reformulated in the light of 'race suicide,' 'depopulation' and the making of racial Jews. Demographic engineering is a loaded category that obfuscates how demographic knowledge constitutes populations to make them available to political intervention it calls for as a necessity.

INDEX

Keywords: Bio-Politics, Demographic Knowledge, Population Theory, Security, Fascism

\section{AUTHOR}

\section{SANDRINE BERTAUX}

IFEA-affiliated researcher 